\title{
Temperature and light requirements for growth of two diatom species (Bacillariophyceae) isolated from an Arctic macroalga
}

\author{
Received: 23 May 2005/ Revised: 13 October 2005/ Accepted: 13 October 2005
}

(C) Springer-Verlag 2005

\begin{abstract}
In the present study, two abundant epiphytic diatom taxa were isolated from the assimilation hairs of the brown macroalga Chordaria flagelliformis collected in the Arctic Kongsfjorden (Spitsbergen, Norway), established as unialgal cultures and their growth rates determined under controlled photon fluence rate and temperature conditions. Using morphological (light and scanning electron microscopy) and SSU rRNA gene data both isolates (ROS D99 and ROS D125) were identified as members of a Fragilaria-Synedropsis clade. The molecular data of ROS D99 and ROS D125 were not identical to any other published sequence. While ROS D99 has been identified as Fragilaria barbararum mainly due to the SEM characteristics, ROS D125 could not be definitely identified although morphological data speak for Fragilaria striatula. Both diatom species showed similar growth rates at all temperatures and photon fluence rates tested. They grew well between 0 and $15^{\circ} \mathrm{C}$ with optimum temperatures of $12-14^{\circ} \mathrm{C}$, but did not survive $20^{\circ} \mathrm{C}$. Therefore, compared to Antarctic diatoms both taxa from Kongsfjorden can be characterised as eurythermal organisms. Increasing photon fluence rates between 2 and $15 \mu \mathrm{mol} \mathrm{m}{ }^{-2} \mathrm{~s}^{-1}$ were accompanied with an almost twofold increase in growth rates, but photon fluence rates $>15 \mu \mathrm{mol} \mathrm{m}{ }^{-2} \mathrm{~s}^{-1}$ did not further enhance growth pointing to low light requirements. From these data optimum, minimum and maximum photon fluence rates and temperatures for growth can be assessed indicating that both diatoms are well acclimated to the fluctuating environmental conditions in the Arctic habitat.
\end{abstract}

U. Karsten $(\varangle) \cdot$ R. Schumann $\cdot$ S. Rothe

Institute of Biological Sciences, Applied Ecology,

University of Rostock, Albert-Einstein-Strasse 3,

18051 Rostock, Germany

E-mail: ulf.karsten@biologie.uni-rostock.de

Tel.: + 49-381-4986090

Fax: + 49-381-4986072

I. Jung $\cdot$ L. Medlin

Alfred-Wegener-Institute for Polar and Marine Research,

Am Handelshafen 12, 27570 Bremerhaven, Germany

\section{Introduction}

Due to their typically high primary production rates benthic diatoms are key organisms in the functioning of trophic webs in intertidal mudflats and shallow water ecosystems of temperate to tropical regions, particularly as a major food source for benthic suspension- or deposit-feeders (Cahoon 1999; Underwood and Kromkamp 1999). Round (1971) characterised the main substratum affinities of these microalgae as epilithic (on rock substrata), epipelic/episammic (on mud and sand, respectively) and epiphytic/epizooic (on macrophytes and animals, respectively). Although most benthic diatoms grow on various geological hard and soft substrata, there are also various taxa living epiphytically on macroalgae where they often form complex assemblages and high abundances.

Epiphytic assemblages of diatoms in marine and brackish water have already been reported decades ago (Main and McIntire 1974, and references therein; Ramm 1977). However, these papers typically describe only the qualitative and quantitative occurrence of the diatom flora associated with selected macrophytes. More recent publications consider environmental factors that may influence the epiphytic diatom flora (e.g. Snoeijs 1995). The latter author investigated the distribution of diatoms epiphytic on the abundant brown macroalga Pylaiella littoralis (Linnaeus) Kjellman at various locations in the Baltic Sea which are characterised by different salinities and wave action. Snoeijs (1995) reported a maximum of 111 diatom taxa. Although the species composition changed with decreasing habitat salinities, the overall species richness remained almost unaffected indicating that epiphytic diatoms as a group are not stressed by the horizontal salinity gradient in the Baltic Sea. However, this hypothesis is mainly based on biogeographical distribution data of individual taxa rather than on ecophysiological experiments under controlled conditions.

The effects of epiphytic microalgae on their host may be either beneficial (e.g. protection against herbivory 
and high insolation) or detrimental (e.g. competition for light and nutrients) (Fong et al. 2000; Brush and Nixon 2002). If epiphytes are present in high cell numbers they may account for up to $50 \%$ of the primary production of a macrophyte community (Pollard and Kogure 1993).

While the ecology of epilithic, epipelic/sammic and epiphytic diatoms in cold-temperate to warm-temperate/ tropical waters is well investigated, similar studies for polar regions are rare, except for psychrophilic forms on and inside the ice (Mock and Gradinger 1999). The Arctic Kongsfjorden at the north-western coast of Svalbard (Spitsbergen, Norway) has received a lot of research attention in recent years as high latitude monitoring site for the impact of climate changes (Hop et al. 2002; Wiencke 2004). Although the structure of the pelagic and benthic food webs in Kongsfjorden is well described, even basic information on the production biology of the different phototrophic organisms is still lacking for most groups, particularly for macro- and microalgae (Hop et al. 2002). In contrast to temperate to tropical regions the ecological significance of microphytobenthic communities for polar waters is not well understood, although a recent pilot study on epilithic diatoms of a high Arctic fjord in Greenland demonstrated for the first time that these algae accounted for about $40 \%$ of the total benthic primary production (Glud et al. 2002).

Arctic microphytobenthos experiences strong seasonal amplitudes in solar radiation. During the long polar night that covers 116 days in the Kongsfjorden area, primary production of all phototrophs is completely suppressed. Later in the season during periods of persisting ice layers in spring, and of melting snow and glaciers in summer resulting in a high discharge of particles into the fjord light penetration into the water column may be extremely low and hence negatively affect photosynthesis and production of all phototrophs (Hanelt et al. 2001). While growth and photosynthesis as a function of the radiation conditions has been investigated for many macroalgal species from Kongsfjorden (Wiencke 2004), similar ecophysiological studies on benthic microalgae are completely missing.

Therefore, the aim of the present study was for the first time to isolate abundant epiphytic diatom taxa from Kongsfjorden macroalgae, to establish unialgal cultures and to determine their growth rate under different photon fluence rate and temperature conditions. From these data optimum, minimum and maximum photon fluence rates and temperatures for growth can be assessed and possible adaptations to the environmental conditions in the Arctic habitat better understood.

\section{Material and methods}

\section{Study site and sampling}

Two recent reviews (Hop et al. 2002; Svendsen et al. 2002) give a comprehensive overview on the actual biological and physical knowledge of Kongsfjorden, a glacial fjord at the northwestern part of Spitsbergen $\left(79^{\circ} \mathrm{N}, 12^{\circ} \mathrm{E}\right)$ (Fig. 1). The fjord extends from north-west to south-east with a length of $26 \mathrm{~km}$ into the inland. The width ranges from 3 to $8 \mathrm{~km}$ with a maximum depth of about $400 \mathrm{~m}$. The tidal range is about $2 \mathrm{~m}$ and its current is weak. Air temperature is higher compared to other locations at these high latitudes, with an annual mean temperature ranging from $-15^{\circ} \mathrm{C}$ in winter to about $5^{\circ} \mathrm{C}$ in summer. The annual mean water temperature is just above $0^{\circ} \mathrm{C}$. Complete ice cover of Kongsfjorden is an exceptional event.

Epiphytically grown diatoms were isolated from the assimilation hairs of the brown macroalgal host Chordaria flagelliformis (O.F. Müller) C. Agardh in the Kongsfjorden. C. Alagelliformis was collected at about $1 \mathrm{~m}$ water depth in July 2002 by SCUBA diving from the sampling site Hansneset at the western part of the island Blomstrandhalvöya (Fig. 1). This brown alga is a typical annual species of the Arctic and cold temperate region of the Northern hemisphere, and shows in Kongsfjorden a vertical distribution between 0.0 and $5.5 \mathrm{~m}$ depth (Wiencke et al. 2004).

The macroalgal host was strongly shaken inside a 11 glass beaker filled with filtered fjord water $(2 \mu \mathrm{m}$ pore size) resulting in a dense suspension of diatom cells and chains. From this suspension micro droplets $(<50 \mu \mathrm{l})$ were transferred into $15 \mathrm{ml}$ sterile North Sea water (32 psu) enriched by $20 \mathrm{ml} \mathrm{l}^{-1}$ Guillards $\mathrm{f} / 2$ (Guillard and Ryther 1962) and $30 \mathrm{mg} \mathrm{l}^{-1}$ sodium metasilicate followed by incubation at $<5^{\circ} \mathrm{C}$ and about $10 \mu \mathrm{mol}$ photons $\mathrm{m}^{-2} \mathrm{~s}^{-1}$ for $1-2$ months to obtain dense cultures. Subsamples were dispensed onto silicate-enriched seawater agar plates $(1.5 \%)$ and incubated for $2-3$ weeks under the same conditions. Individual colonies were transferred into $5 \mathrm{ml} \mathrm{f} / 2$ enriched seawater medium (see above) and allowed to grow dense cultures again. These were checked microscopically if they were unialgal. However, most of the cultures had to be further cleaned from rare, contaminating taxa by picking single cells or cell chains with a capillary and checking the droplet microscopically for unialgality. Finally, the unialgal suspensions were grown in $100 \mathrm{ml}$ Erlenmeyer flasks in sterile $f / 2$ enriched North Sea water medium at $10-15 \mu \mathrm{mol}$ photons $\mathrm{m}^{-2} \mathrm{~s}^{-1}$ as pre-cultures for the growth measurements.

\section{Light and scanning electron microscopy}

Light microscopical analysis of living diatoms was performed using an Olympus IX70 microscope (UPlanApo $60 \mathrm{NA} 1.2 \mathrm{~W} \times 1.5$ magnification by a IX-CA2X prism) equipped with a differential interference contrast. For the frustule preparation culture material was washed with distilled water to remove extracellular salts, treated with $10 \% \mathrm{HCl}$ for $24 \mathrm{~h}$ at room temperature, washed with distilled water and then incubated in $35 \%$ hydrogen peroxide for $3-4 \mathrm{~h}$ at $100^{\circ} \mathrm{C}$ to oxidise all organic material. After gentle centrifugation at 
Fig. 1 Map of the study area in the Kongsfjorden at the northwestern coast of Spitsbergen. The sampling site Hansneset at the western part of the island Blomstrandhalvöya is marked with an asterisk

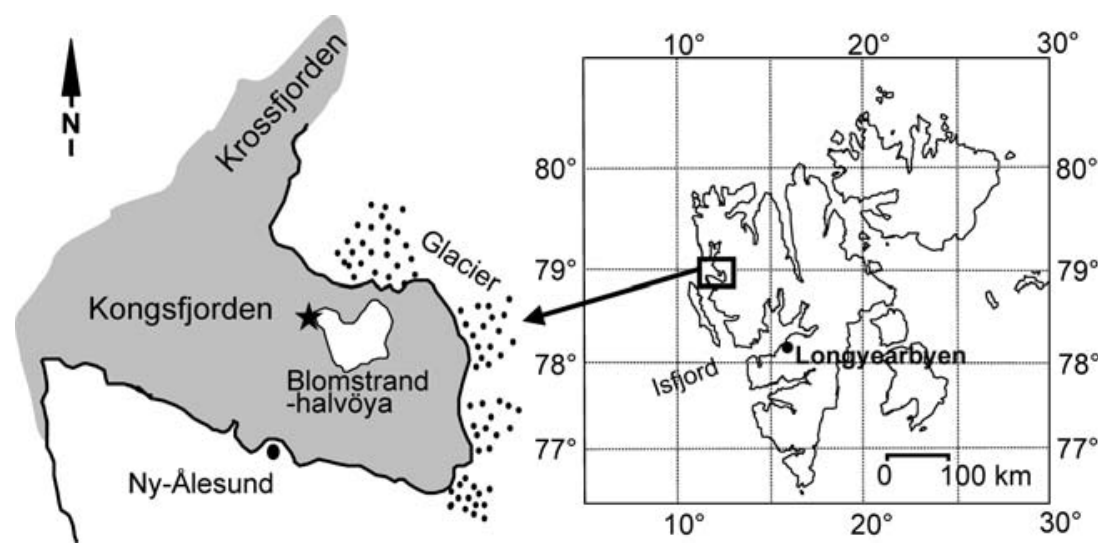

about $1,000 \mathrm{~g}$ the pellets were washed several times with distilled water until the $\mathrm{pH}$ value was neutral. A droplet of the suspension of frustules was transferred by a micropipette to coverslips, air-dried and a small amount of NAPHRAX ${ }^{\circledR}(\mathrm{RI}=1.71$; Dr. Thorns, Biologie-Bedarfs-Handel, Göttingen, Germany) added as mounting medium to prepare permanent diatom slides. Frustules were observed with an Olympus BX51 (UPlan FL 100 NA 1.3 Oil). Digital images were taken with a SIS Color View 12 camera (AnalySIS Pro PC EXT software).

For scanning electron microscopy diatom cells of both strains were preserved with $4 \%$ formaldehyde and later washed with distilled water. A droplet of this suspension was air-dried on an aluminium SEM holder and sputter coated with gold for $45 \mathrm{~s}$ using an Agar Sputter Coater (Agar Scientific Ltd, Essex, UK). Observations were performed on a Hitachi S-4500 field emission scanning electron microscope at accelerating voltages of $5 \mathrm{kV}$, and at a magnification range of 5.000 to 10.000 .

\section{Growth measurements}

Cell suspensions growing in the logarithmic phase were derived from batch cultures grown at $5^{\circ} \mathrm{C}, 10$ $15 \mu \mathrm{mol}$ photons $\mathrm{m}^{-2} \mathrm{~s}^{-1}$ in sterile $\mathrm{f} / 2$ enriched North Sea water medium. These were diluted prior to the experiment 1,000-fold and portioned into $5 \mathrm{~cm}$ diameter polyethylene dishes at a volume of $15 \mathrm{ml}$ each. Fifteen dishes per species were incubated at $0,5,10,15$ and $20^{\circ} \mathrm{C}$, respectively. The temperature deviation at all conditions was $\pm 0.4^{\circ} \mathrm{C}$. Osram Daylight Lumilux Deluxe lamps were used as light sources. Different photon fluence rates were obtained by shading the dishes with up to four layers of black gauze resulting in 2, 5, 10, 15 and $20 \mu \mathrm{mol}$ photons $\mathrm{m}^{-2} \mathrm{~s}^{-1}$. Radiation measurements were carried out with a Li-Cor LI-190-SB cosine corrected sensor connected to a Li-Cor LI-1000 datalogger (Lambda Instruments, Lincoln, USA) at the surface of the dishes (sensor error $<2 \%$ ). All cultures were grown under continuous light. The number of replicates was three.
Growth rates were determined fluorometrically using a Hansatech MFMS fluorimeter (Hanatech Instruments Ltd, Kings Lynn, UK). All methodological considerations using this system for growth measurements of benthic microalgae are discussed in Karsten et al. (1996). Each dish was placed into the fluorometer always in the same orientation to minimise noise originating from the dishes' material and measured three times for chlorophyll fluorescence of the sedimented or attached diatom cells. Medium blanks were measured daily and were subtracted from sample values. Each sample was monitored for up to 14 days every $24 \mathrm{~h}$ or for faster growth, particularly at 10 and $15^{\circ} \mathrm{C}$, for up to 7 days every $12 \mathrm{~h}$. Maximum fluorescence units at the end of the logarithmic growth phase were approximately 1,500.

The growth rate for each individual sample was calculated from the logarithmic growth equation by the following procedure: According to

$N_{\mathrm{t}}=N_{0} \mathrm{e}^{\mu t}$

where

$N_{0}$ : fluorescence at day 0

$N_{\mathrm{t}}$ : fluorescence at a given day

$\mu$ : growth rate in logarithmic phase $\left(\right.$ day $\left.^{-1}\right)$

$t$ : time (day)

$N_{\mathrm{t}}$ was calculated for each measurement from an estimated $\mu$. The squared differences between measured and calculated $N_{\mathrm{t}}$ were summed. With the Solver function of the Microsoft Excel calculation program $\mu$ was iterative optimised for a minimum deviation between measured and calculated $N_{\mathrm{t}}$. Mean $\mu$ was calculated from three replicate samples for each temperature and photon fluence rate.

\section{DNA extraction and phylogeny}

Nucleic acids were extracted according to a quick-andready protocol developed by Dr. Klaus Valentin (Alfred-Wegener-Institute, Bremerhaven, Germany, personal communication). Culture material was centrifuged at 5,200g and the supernatant was discarded. The 
pellets were shock-frozen in liquid nitrogen and subsequently incubated at $95-98^{\circ} \mathrm{C}$ for $2-3 \mathrm{~min}$. This was repeated twice. After a final centrifugation step for 1-2 min at $16,000 \mathrm{~g}$ at $4^{\circ} \mathrm{C}$, the supernatants were used as PCR template solution.

PCR amplification of the small subunit rRNA gene (SSU rDNA) was done in a Mastercycler gradient (Eppendorf, Hamburg, Germany) with the primer pairs $1 \mathrm{~F}$ and 1528R (Medlin et al. 1988, without polylinker). Conditions for PCR were as follows: initial denaturation at $94^{\circ} \mathrm{C}$, followed by 36 cycles of $94^{\circ} \mathrm{C}$ for $2 \mathrm{~min}, 54^{\circ} \mathrm{C}$ for $4 \mathrm{~min}$, and $72^{\circ} \mathrm{C}$ for $2 \mathrm{~min}$, and a final extension at $72^{\circ} \mathrm{C}$ for $10 \mathrm{~min}$. Quantity and length of products were examined by agarose gel electrophoresis against a known standard. PCR products were cleaned with a QiaQuick PCR purification kit (Quiagen, Hilden, Germany). Sequencing reactions were carried out using the BigDye Terminator v3.1 Cycle Sequencing Kit (Applied Biosystems, Foster City, CA, USA). In addition to the primers used in the PCR reaction (Medlin et al. 1988), a set of four additional sequencing primers was used: 528F, 1055F, 536R and 1055R (Elwood 1985, slightly modified) (Table 1). Unincorporated ddNTPs and other PCR reagents were removed by DyeEx Spin Kit (Quiagen) with kit columns rinsed with $300 \mathrm{ml}$ HPLC quality water. Purified sequencing products were mixed with $10 \mu \mathrm{l}$ formamide and electrophoresed on an ABI 3100 Avant sequencer (Applied Biosystems).

Basecalling was examined and sequences were assembled using the programs SeqMan (DNASTAR, Madison, WI, USA) and SeqScape (Applied Biosystems).

The sequences determined for this study were deposited in the GenBank database under accession numbers AJ971376 (ROS D99, Fragilaria barbararum) and AJ971377 (ROS D125, Fragilaria cf. striatula).

Thirty-seven SSU rDNA sequences of araphid diatoms, as well as those of two raphid and two mediophycean centric species, were downloaded from GenBank (Table 2). Sequences were aligned using Clustal X (Thompson et al. 1997), and alignment was checked manually using ProSeq (Filatov 2002). A region of $56 \mathrm{bp}$, in which all sequences used could not be aligned unambiguously (including both strains studied), was excluded from the analysis, as is usually recom- mended for unreliable parts of alignments (Higgins and Salemi 2003).

Phylogenies were reconstructed using PAUP* (Swofford 2002). The data set was subjected to a hierarchical likelihood ratio test (hLRT) using ModelTest (Posada and Crandall 1998) to ascertain the appropriate model of evolution. The evolutionary model selected corresponded to the general time reversible model with a gamma distribution of substitution rates at variable sites (shape parameter $\alpha=0.43$ ) and an assumed proportion of invariable sites of $0.4832(\mathrm{GTR}+\mathrm{G}+\mathrm{I}$ model); the nucleotide frequencies were assumed to be $\mathrm{A}=0.24450$, $\mathrm{C}=0.18540, \mathrm{G}=0.27140$ and $\mathrm{T}=0.29870$, with base substitution rates of $\mathrm{A} \mathrm{C}=1, \mathrm{~A} \mathrm{G}=2.1334$, $\mathrm{A} \mathrm{T}=1$, $\mathrm{C} G=1, \mathrm{C} \mathrm{T}=4.2027$ and $\mathrm{G} T=1$. These model test parameters were implemented in heuristic search neighbour-joining (NJ) analysis and NJ-based heuristic search maximum likelihood (ML) analysis. In addition, a maximum parsimony (MP) tree was inferred using the heuristic search option and random taxa addition. Bootstrap majority-rule consensus trees were calculated from 1,000 bootstrap replicates using NJ and MP.

\section{Statistics}

Mean values of growth rates and standard deviations were calculated from three independent replicates per treatment. Statistical significance of means was tested by one-way ANOVA followed by a Fisher's protected least significant difference test (LSD) (Sokal and Rohlf 1995).

\section{Results}

Isolate ROS D99 is a 6-12 $\mu \mathrm{m}$ long, 6-7 $\mu \mathrm{m}$ wide and 4-6 $\mu \mathrm{m}$ high pennate diatom (Fig. 2a). It forms chains of about 50-100 cells (Fig. 2b), also under natural conditions. Isolate ROS D125 is about $20-45 \mu \mathrm{m}$ long, 6-7 $\mu \mathrm{m}$ wide and 5-7 $\mu \mathrm{m}$ high (Fig. 2c). Living cells can have a slightly asymmetric shape in top view (Fig. 2d). This species attaches to surfaces with one end and forms only short ribbon-like chains of up to ten cells if unattached (Fig. 2e). Bacterial numbers in the cultures were generally low.

Table 1 Primers used for amplification and sequencing of the small subunit rRNA gene (SSU rDNA). All primers presented in $5^{\prime} \rightarrow 3^{\prime}$ direction

\begin{tabular}{llll}
\hline Designation & Application(s) & Sequence & Author \\
\hline $1 \mathrm{~F}$ & $\begin{array}{l}\text { PCR and sequencing } \\
\text { of SSU rDNA-forward primer }\end{array}$ & AAC CTG GTT GAT CCT GCC AGT & $\begin{array}{c}\text { Medlin et al. (1988), } \\
\text { without polylinker }\end{array}$ \\
$1528 \mathrm{R}$ & $\begin{array}{l}\text { PCR and sequencing } \\
\text { of SSU rDNA-reverse primer }\end{array}$ & TGA TCC TTC TGC AGG TTC ACC TAC & \\
$528 \mathrm{~F}$ & Sequencing of the & GCG GTA ATT CCA GCT CCA A & Elwood (1985), some primers \\
$1055 \mathrm{~F}$ & SSU rDNA-forward primers & GGT GGT GCA TGG CCG TTC TT & slightly modified \\
$536 \mathrm{R}$ & Sequencing of the & AAT TAC CGC GGC KGC TGG CA & \\
$1055 \mathrm{R}$ & SSU rDNA-reverse primers & ACG GCC ATG CAC CAC CAC CCA T & \\
\hline
\end{tabular}




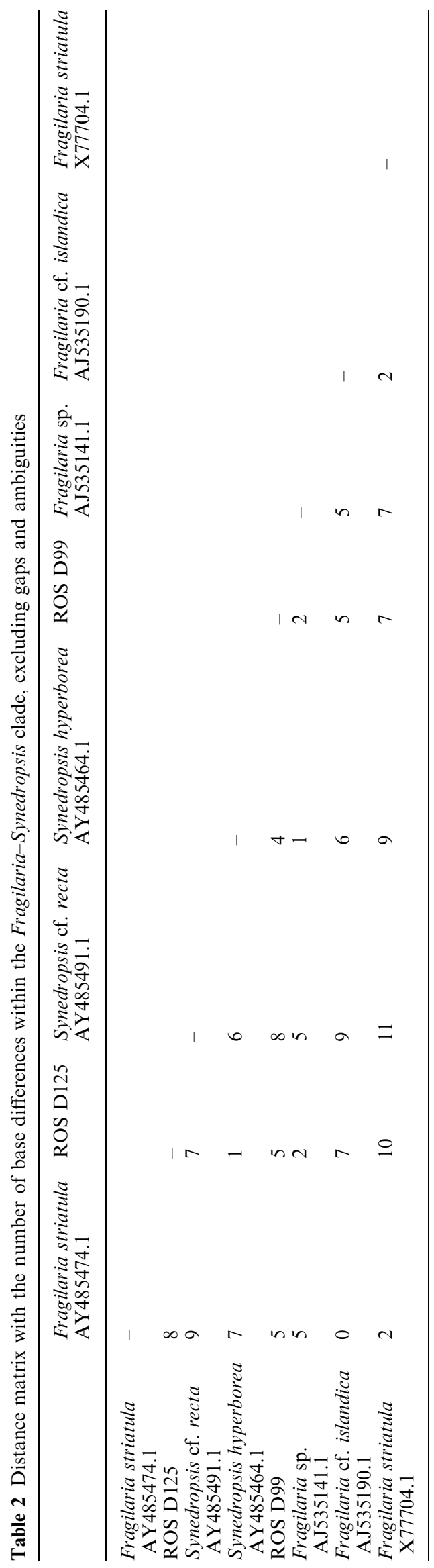

SEM studies indicate the valves of ROS D99 to appear linear-elliptical in shape with a broad girdle composed of numerous punctate bands (Fig. 3a). This isolate has an almost indistinct, linear but very narrow sternum, and finely punctated transapical striae consisting of single rows of areolae. At both tips of the valve a well-circumscribed area of minute pores (pore field) occur (Fig. 3b). This morphology is congruent with the description of $F$. barbararum by Witkowski, Metzeltin and Lange-Bertalot (Metzeltin and Witkowski 1996), and has been confirmed on the SEM pictures by Prof. Witkowski and Prof. Lange-Bertalot.

In contrast to isolate ROS D99, valves of ROS D125 appear in the SEM as linear-lanceolate with obtusely rounded apices (Fig. 3c). Similar to ROS D99 this strain exhibits also an almost indistinct, linear but very narrow sternum, as well as uniseriate striae (Fig. 3c, d). However, compared to ROS D99, the areolae are much smaller. Pore fields are visible at both tips of the frustules (Fig. 3d). This morphology is congruent with the description of Fragilaria striatula Lyngbye (Witkowski et al. 2000), as well as with light microscopic (Snoeijs 1993) and SEM pictures (Poulin et al. 1986). In addition, based on the SEM pictures Prof. Witkowski and Prof. Lange-Bertalot confirmed ROS D125 as F. striatula.

In ML analysis, ROS D99 and ROS D125 clustered in a clade containing the marine Fragilariaceae Synedropsis hyperborea, Synedropsis cf. recta, Fragilaria sp., Fragilaria cf. islandica and two F. striatula sequences. This clade will be called Fragilaria-Synedropsis clade (FS clade) in the remainder of this paper.

Figure 4 shows the phylogenetic tree inferred from a ML analysis of 43 sequences, with bootstrap support from NJ and MP analyses. Twenty-eight taxa are collapsed into the triangle marked outgroup. Bootstrap support for the monophyly of the FS clade was high, 98 (NJ) and 97 (MP). Support values for the within-clade resolution were very low in both likelihood and bootstrap analysis. But the only well-supported branch within the group was the one grouping the $F$. striatula and $F$. cf. islandica sequences.

The dataset contained 317 parsimony-informative characters. MP analysis (not shown) yielded 37 most parsimonious trees; their strict consensus tree displayed the $F S$ clade as a polytomy, with the F. striatula- $F$. cf. islandica clade as the only inner node resolved. A MP majority-rule consensus tree and a NJ tree (not shown) differed from the ML tree in the exact branching order. In all three trees, ROS D99 was the sister group to a clade consisting of the $F$. striatula and $F$. cf. islandica sequences. Nevertheless, the bootstrap support for this group was below $60 \%$ for both bootstrap analyses.

In all phylogenies in which the inner structure of the FS clade was resolved, ROS D125 formed a monophyletic clade with $S$. hyperborea. Bootstrap support values for the latter clade were only $87(\mathrm{NJ})$, and below the threshold for the MP. In all three phylogenies, the genus Synedropsis was paraphyletic: all monophyletic groups 
Fig. 2 Light microcopic pictures of two epiphytic diatom species (ROS D99-a $\mathbf{b}$; ROS D125-c-e) isolated from the brown alga Chordaria flagelliformis using an Olympus IX70 microscope equipped with a differential interference contrast. ROS D99 often forms also under natural conditions chains (b). All scale bars $=10 \mu \mathrm{m}$
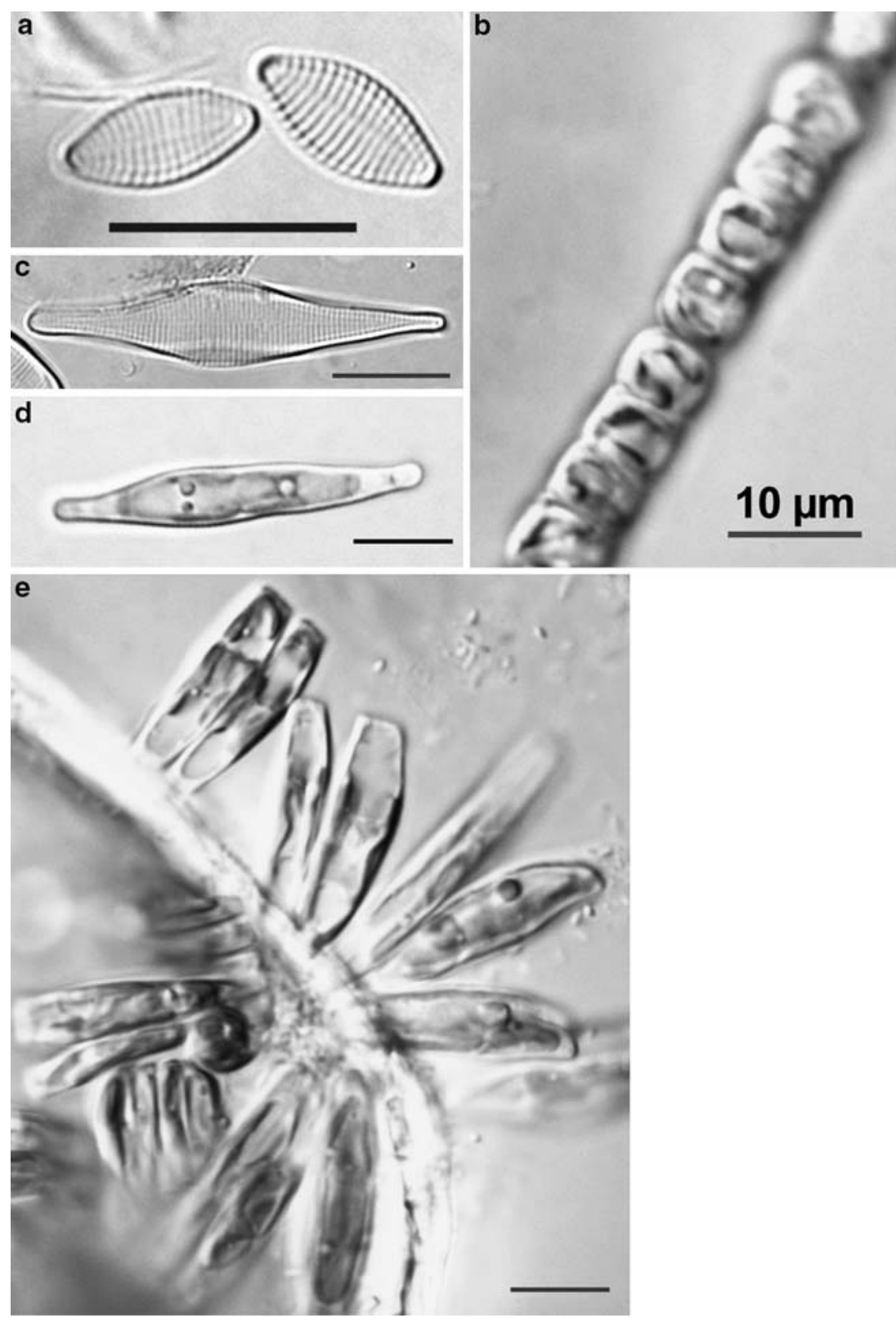

containing the two Synedropsis sequences contained the Fragilaria sequences as well.

The sequences of the isolates were not identical to any sequence already published in GenBank. The number of base differences within the FS clade was low (see distance matrix in Table 2). ROS D125 differed in only $1 \mathrm{bp}$ from $S$. hyperborea, but by 8 and $10 \mathrm{bp}$ from the two F. striatula sequences. The two Synedropsis species differed by 6 bp.

Both isolates ROS D99 and ROS D125 showed similar growth rates at all temperatures and photon fluence rates tested (Figs. 5, 6). At $0^{\circ} \mathrm{C}$ both diatoms grew exponentially and differed only in the duration of lag phases, which was about 1-2 days for ROS D99 and 4 days for ROS D125 (data not shown). Photon fluence rates did not influence growth rates at this low temper- ature ( $\mu$ values of $0.32-0.35 \mathrm{day}^{-1}$ ) or only to a very low extent (Figs. 5, 6) $(P>0.05)$. At $5^{\circ} \mathrm{C}$ increasing photon fluence rates from 2 to $15 \mu \mathrm{mol} \mathrm{m} \mathrm{m}^{-2} \mathrm{~s}^{-1}$ were accompanied with a small, but almost linear increase in growth, i.e. in ROS D99 $\mu$ rose from 0.38 to 0.56 , and in ROS D125 from 0.45 to $0.60(P<0.01)$. Photon fluence rates $>15 \mu \mathrm{mol} \mathrm{m} \mathrm{m}^{-2} \mathrm{~s}^{-1}$ did not enhance growth indicating low light requirements. Temperatures of 10 and $15^{\circ} \mathrm{C}$ led in both isolates to a strong stimulation of growth (Figs. 5, 6; $P<0.001$ ). While ROS D99 showed an increase in $\mu$ from 0.49 to $0.97 \mathrm{day}^{-1}$ with increasing photon fluence rates, ROS D125 exhibited a similar trend but on a higher level with $\mu$ values between 0.68 and $1.24 \mathrm{day}^{-1}$. In both isolates at 10 and $15^{\circ} \mathrm{C}$ photon fluence rates $>15 \mu \mathrm{mol} \mathrm{m} \mathrm{m}^{-2} \mathrm{~s}^{-1}$ did not further stimulate growth (Figs. 5, 6; $P>0.05$ ). Although ROS D99 
Fig. 3 Scanning electron microscopic view on cleaned diatom cells of isolate ROS D99 (a) and ROS D125 (c). ROS D99 exhibits linear-elliptical valves with a broad girdle composed of numerous punctate bands, and at both tips a well-circumscribed pore field (b). ROS D125 shows linear-lanceolate valves with obtusely rounded apices, as well as pore fields at both tips of the frustules (d)
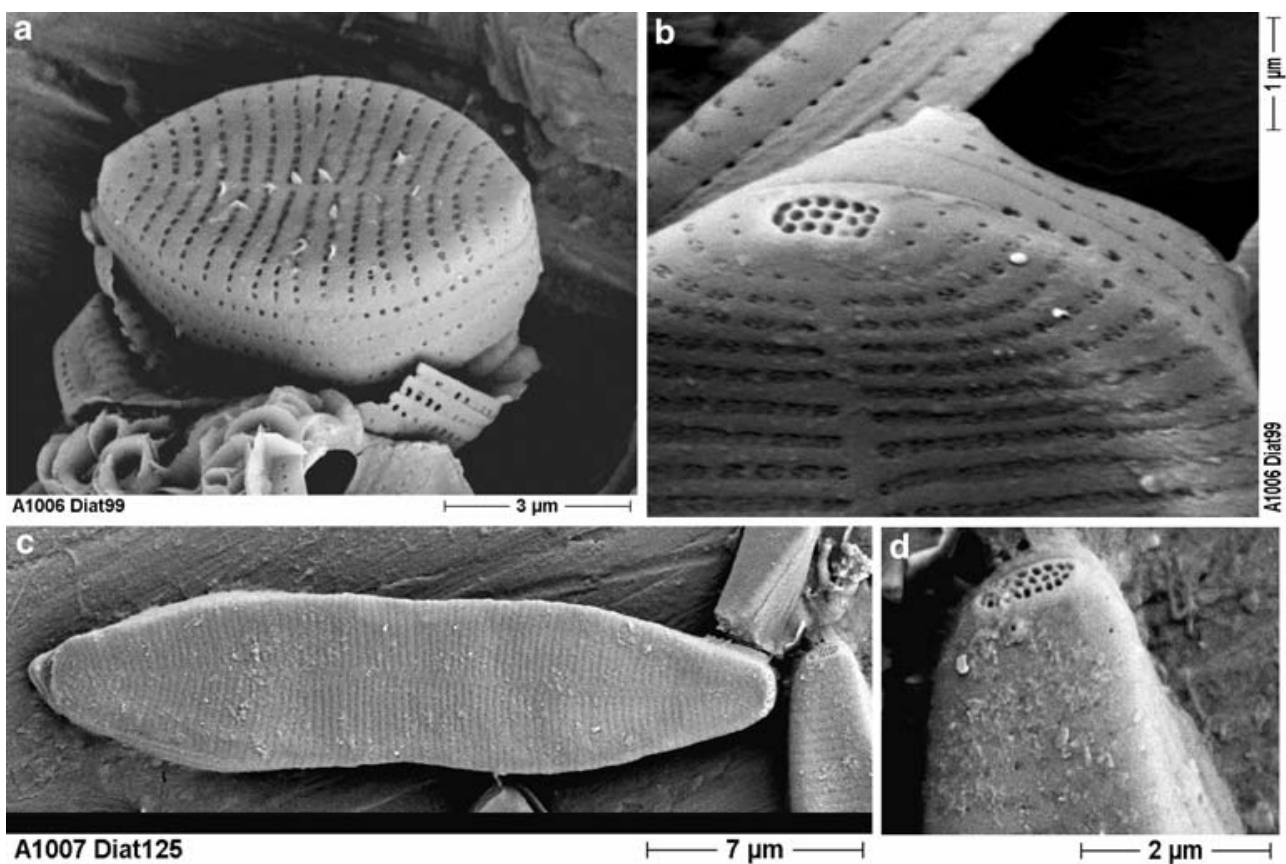

and ROS D125 showed a similar growth pattern, the latter isolate grew about $25 \%$ faster at $15^{\circ} \mathrm{C}$. Both strains did not survive long-term incubation at $20^{\circ} \mathrm{C}$. While ROS D99 died immediately after transfer from 5 to $20^{\circ} \mathrm{C}$ as seen by negative growth rates resulting from decreasing fluorescence signals due to bleaching, ROS D125 grew at least 4 days before cells started to die (Fig. 7). If growth rates were fitted against temperature according to the mathematical equation of Blanchard et al. (1996) optimum temperatures of $12-14^{\circ} \mathrm{C}$ were calculated for both isolates (data not shown). At $0^{\circ} \mathrm{C}$ ROS D99 and ROS D125 could still sustain one-third of optimal growth. At the lowest photon fluence rate of $2 \mu \mathrm{mol} \mathrm{m}{ }^{-2} \mathrm{~s}^{-1}$ the $\mu$ value measured at $15^{\circ} \mathrm{C}$ (near the calculated optimum rate) was still $50 \%$ compared to the highest value measured at $20 \mu \mathrm{mol}$ photons $\mathrm{m}^{-2} \mathrm{~s}^{-1}$.

\section{Discussion}

The macroalgal flora of the Arctic Kongsfjorden consists of about 30-40 taxa of mainly cold temperate origin (Wiencke et al. 2004). While on hard-bottom locations such as Hansneset high vertical standing stocks between 0 and $30 \mathrm{~m}$ depth can be formed by macroalgae, their possible significance as host for epiphytes has not been studied before in Arctic waters. During a pilot study epiphytic diatoms on macroalgae from Kongsfjorden were studied, and high abundances were observed particularly on host plants from shallow water $(0.5-5 \mathrm{~m})$. Thalli area of macroalgal species such as the chlorophyte Acrosiphonia sp. or the phaeophytes Ectocarpus siliculosus (Dillwyn) Lyngbye, Elachista fucicola (Velley) Areschoug and P. littoralis (Linnaeus) Kjellman can be $70-90 \%$ covered by approximately 20-25 epiphytic diatom taxa (Karsten et al. unpublished results), which typically represent members of the genera Amphora, Cocconeis, Fragilaria, Licmophora, Navicula, Nitzschia and Rhabdonema. In addition, the assimilation hairs of the brown alga $C$. flagelliformis exhibited also an almost complete coverage with various epiphytic diatom taxa, of which two were isolated and successfully established as unialgal cultures at the University of Rostock. These species were for the first time ecophysiologically characterised in terms of growth under different temperatures and photon fluence rates. Both isolates ROS D99 and ROS D125 exhibited optimum growth rates at $12-14^{\circ} \mathrm{C}$, grew still well but with a reduced rate at $0^{\circ} \mathrm{C}$ and did not survive $20^{\circ} \mathrm{C}$. Therefore, both taxa from Kongsfjorden can be characterised as eurythermal organisms. This is in contrast to Antarctic benthic diatoms which showed maximum growth at $0^{\circ} \mathrm{C}$ and full inhibition of cell division already at $7-9^{\circ} \mathrm{C}$ (Longhi et al. 2003). Consequently, the studied Antarctic microphytobenthic taxa are characterised as polar stenothermal organisms. These obvious differences in the temperature requirements for growth in Arctic and Antarctic benthic microalgae can be related to the hydrological conditions and the geological cold water history of both regions.

Kongsfjorden is an open fjord under the influence of both Atlantic water as well as glacial input. Because of the Atlantic influence the fjord is to be regarded as sub-Arctic rather than Arctic, despite its location at high latitude (Hop et al. 2002), and based on the zoogeographical composition western Spitsbergen is classified as a transition zone between Arctic and boreal regions (WlodarskaKowalczuk et al. 1998). Also most of the macroalgal taxa found in Kongsfjorden have their main distribution in the cold temperate North Atlantic and North Pacific (Wie- 


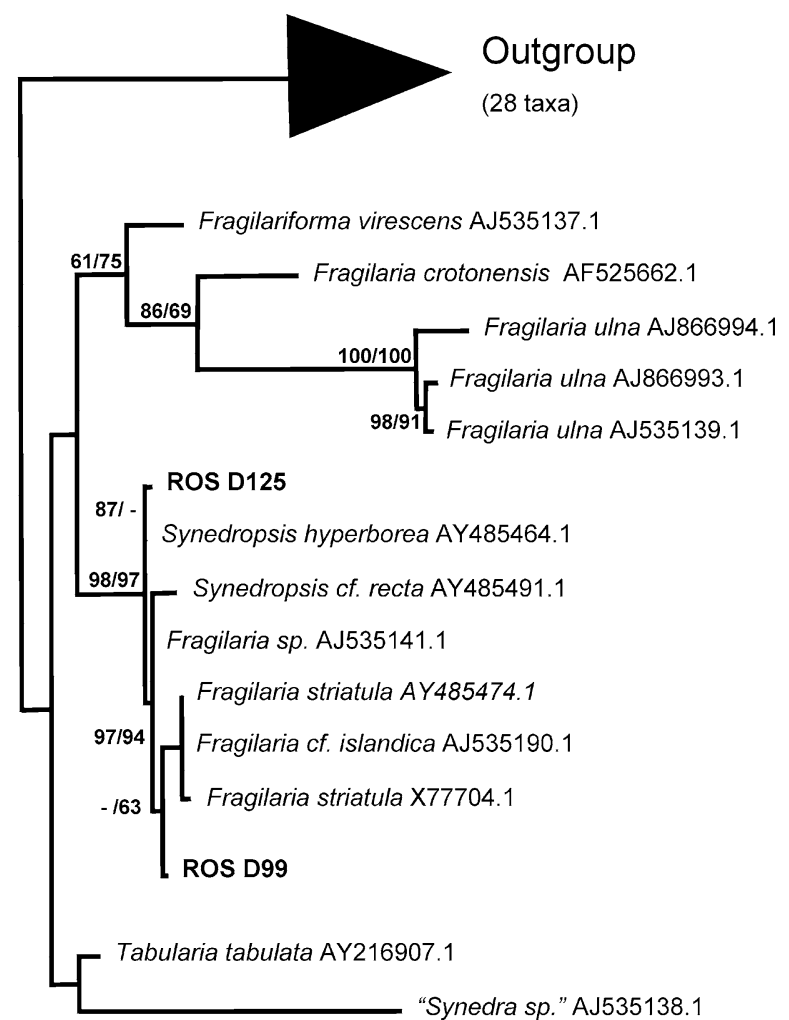

"Synedra sp." AJ535138.1

diatom taxa investigated by Longhi et al. (2003) are characterised as endemic species, which well explains the low temperature demands for growth, the respective information on both strains from the Arctic is still missing due to some unresolved taxonomic problems. However, as already mentioned above, it seems highly unlikely to expect epiphytic diatoms endemic to the Arctic.

Both ROS D99 and ROS D125 grew optimally already at very low photon fluence rates of $10-20 \mu \mathrm{mol}$ photons $\mathrm{m}^{-2} \mathrm{~s}^{-1}$, indicating shade adaptation. Even at the lowest photon fluence rate tested $(2 \mu \mathrm{mol}$ photons $\mathrm{m}^{-2} \mathrm{~s}^{-1}$ ) half of the maximum growth rate could be measured. Similar results were reported for Antarctic benthic diatoms. Gyrosigma subsalinum exhibited saturated growth at $11.4 \mu \mathrm{mol}$ photons $\mathrm{m}^{-2} \mathrm{~s}^{-1}$ (Longhi et al. 2003), and Amphora antarctica and Trachyneis aspera grew also best under very similar conditions at $10-15 \mu \mathrm{mol}$ photons $\mathrm{m}^{-2} \mathrm{~s}^{-1}$ (Rivkin and Putt 1987). However, while these authors documented maximum cell divisions for the Antarctic benthic diatoms in the range of $0.25-0.4$ day $^{-1}$ under optimum photon fluence rates, both Arctic strains grew much faster under similar conditions with growth rates of $0.9-1.2$ day $^{-1}$.

Since the epiphytic diatoms observed on the assimilation hairs of $C$. flagelliformis form in most cases dense assemblages (Karsten et al. unpublished results), selfshading effects have also taken into account (Pillsbury and Lowe 1999). Self-shading may drastically reduce the incident radiation available for cellular photosynthesis, and hence adaptation or acclimation to low light conditions is essential for long-term survival. In addition, the extremely low light requirements for growth of both epiphytic diatoms studied guarantee biomass production under the fluctuating radiation conditions in Kongsfjorden. Hanelt et al. (2001) monitored over several years solar radiation in Kongsfjorden, and described the underwater light climate as seldom stable. Due to rapidly changing weather conditions not only on a seasonal scale, but also diurnally extremely variable radiation can be recorded. In addition, during summer the underwater light climate of Kongsfjorden is further affected by calving glaciers and strong melt water influx resulting in increasing turbidity due to suspended particles and hence in a strong decrease of the water column transmittance. Under these conditions, Kongsfjorden can be optically characterised as coastal water type 9 according to Jerlov (1976) indicating very low light conditions already below 1-2 $\mathrm{m}$ depth. Therefore besides selfshading, the shade adaptation of the epiphytic diatoms can be well explained by the prevailing photon fluence rates in the water column. In addition, in some years after a long cold winter sea-ice plus a top layer of snow may persist until late spring resulting in a very strong attenuation of the impinging solar radiation (Hanelt et al. 2001). Under such circumstances PAR of only $6.5 \mu \mathrm{mol}$ photons $\mathrm{m}^{-2} \mathrm{~s}^{-1}$ can be measured under the ice, which is very low but still sufficient to support growth of both epiphytic diatom species studied. 
Fig. 5 The effect of increasing photon fluence rates on the growth rate of isolate ROS D125 kept at $0,5,10$ and $15^{\circ} \mathrm{C}$. Data shown represent the mean values $\pm \mathrm{SD}(n=3)$
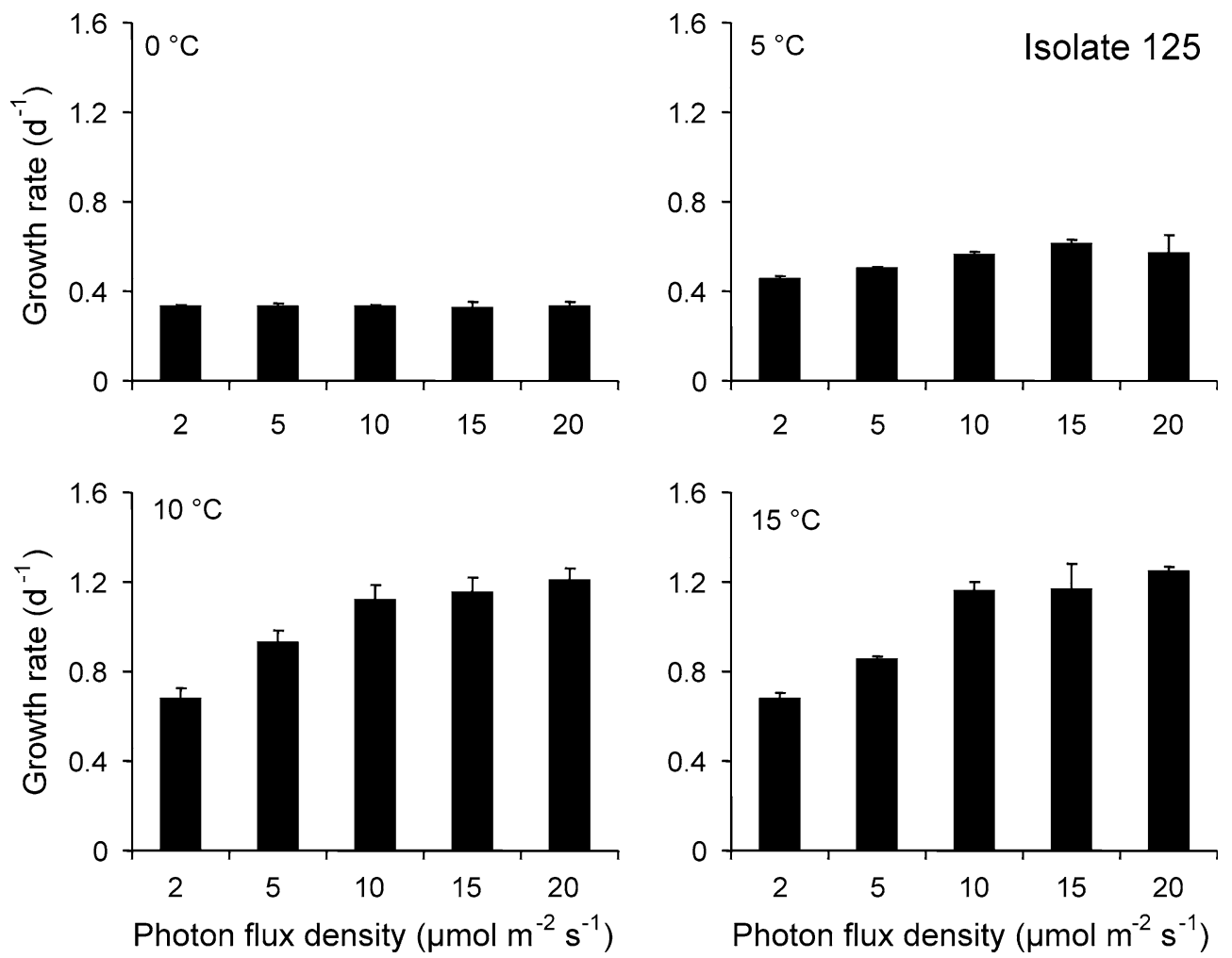

Fig. 6 The effect of increasing photon fluence rates on the growth rate of isolate ROS D99 kept at $0,5,10$ and $15^{\circ} \mathrm{C}$. Data shown represent the mean values $\pm \operatorname{SD}(n=3)$
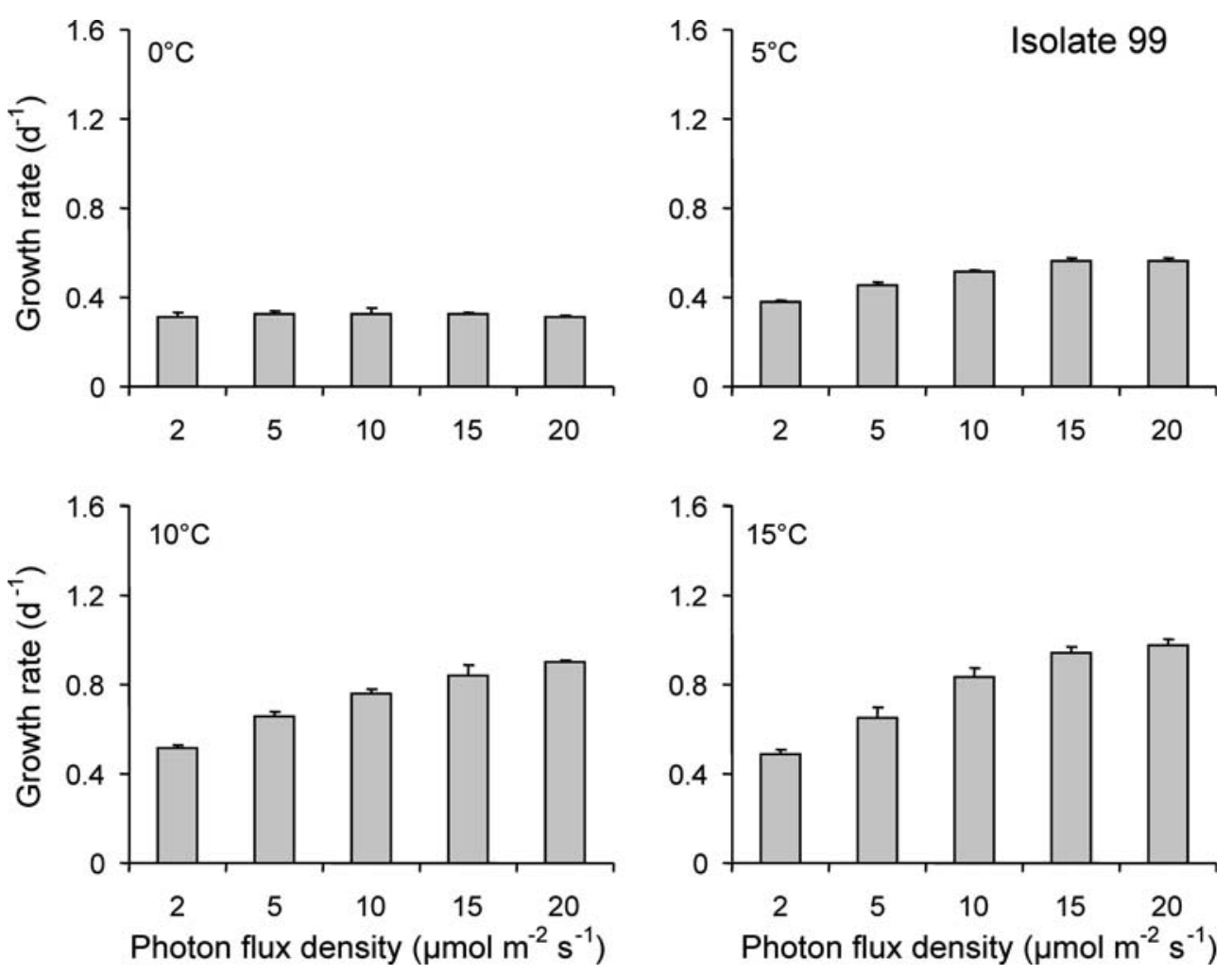

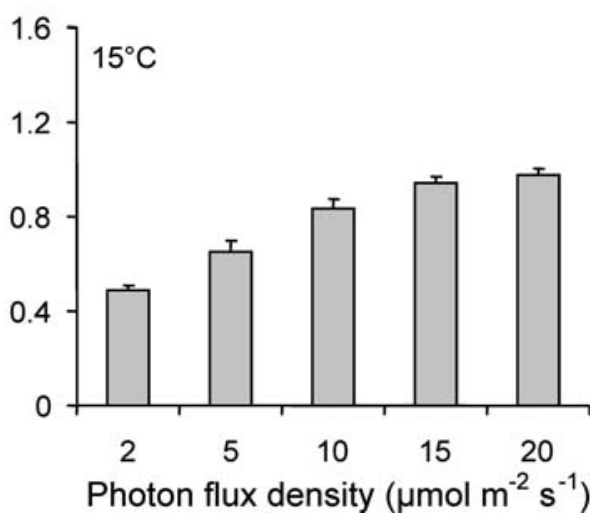

As shown by our phylogenetic analyses based on the SSU rRNA gene, the isolates ROS D99 and ROS D125 are closely related to $F$. striatula and the Synedropsis species. The analyses strongly supported that the two isolates studied belong to a monophyletic FS clade consisting of $S$. hyperborea, $S$. cf. recta, Fragilaria sp., $F$. cf. islandica and two F. striatula sequences. This clade was recovered in all analyses and highly supported by 


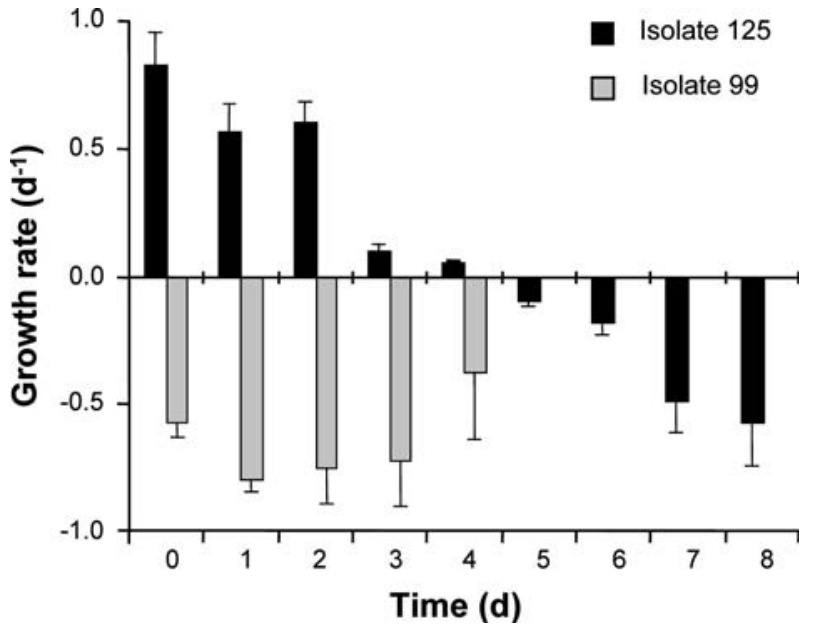

Fig. 7 Growth rates of both isolates ROS D99 and ROS D125 at $20^{\circ} \mathrm{C}$ and $15 \mu \mathrm{mol}$ photons $\mathrm{m}^{-2} \mathrm{~s}^{-1}$ over a period of 8 days. Data shown represent the mean values $\pm \mathrm{SD}(n=3)$

bootstrap values. It is not related with the freshwater representatives of the genus Fragilaria, as has been noted earlier (Medlin et al. 2000).

Resolution of the SSU rDNA proved insufficient to resolve phylogenetic relationships within the FS clade. Base differences were fairly low, tree topologies were unstable and the inner nodes of this clade were not supported by bootstrap analyses and likelihood values. In order to obtain a reliable estimate of relationships within the FS clade, the species in question should be studied using more rapidly evolving genes.

The SSU rDNA sequences obtained were not fully conclusive concerning the problem of the identification of these diatoms. The SSU rDNA sequences of the isolates ROS D99 and ROS D125 were not identical to any other published sequence and are likely different species. ROS D99 has been identified as F. barbararum, mainly due to the SEM characteristics.

The case of the other isolate is more problematic. The sequence of ROS D125 differed by only $1 \mathrm{bp}$ from that of $S$. hyperborea, and by 8 or $10 \mathrm{bp}$ from the two sequences attributed to $F$. striatula in GenBank, respectively. Morphological features of ROS D125, however, are incongruent with the genus description of Synedropsis (Hasle et al. 1994), but are congruent with the species description of $F$. striatula (Witkowski et al. 2000). Given the data at hand, it is impossible to decide which of the sequences should be considered to belong to the "real" $F$. striatula. Each of the sequences whose identification has been attributed to F. striatula is different and they do not form a monophyletic group.

In conclusion, the epiphytic diatoms ROS D99 (Fragilaria barbarum) and ROS D125 (probably $F$. striatula) studied seem to be well adapted to the temperature and radiation conditions in the Arctic Kongsfjorden. However, the temperature requirements clearly indicate eurythermal features and the radiation requirements low-light characteristics. Measurement of growth rates under different environmental conditions is ecologically very important because they reflect an integrating process for all physiological responses in the cell.

Acknowledgements This study was financially supported by the Deutsche Forschungsgemeinschaft (DFG) (KA 899/12-1) and the German Hochschulwissenschaftsprogramm (HWP) through the University of Rostock (Project no. 0050 0570). The authors would like to thank the Ny-Allesund International Research and Monitoring Facility for their support, the AWI diving team for providing field samples, Sybille Müller for technical help with the diatom cultures, as well as Manfred Ruppel, University of Frankfurt, for providing the SEM pictures. Prof. Andrzej Witkowski, University of Sczecin, Poland, Prof. Horst Lange-Bertalot, University of Frankfurt and Dr. Richard Crawford, Alfred-Wegener-Institute, were extremely helpful with the morphological identification of both isolates.

\section{References}

Barron JA (1993) Diatoms. In: Lipps JE (ed) Fossil prokaryotes and protists. Blackwell Scientific Publishers, Boston, pp 155167

Blanchard GF, Guarini JM, Richard P, Gros P, Mornet F (1996) Quantifying the short-term temperature effect on light-saturated photosynthesis of intertidal microphytobenthos. Mar Ecol Prog Ser 134:309-313

Brush MJ, Nixon SW (2002) Direct measurements of light attenuation by epiphytes on eelgrass Zostera marina. Mar Ecol Prog Ser 238:73-79

Cahoon LB (1999) The role of benthic microalgae in neritic ecosystems. Oceanogr Mar Biol Annu Rev 37:47-86

Elwood HJ, Olson GJ, Sogin ML (1985) The small-subunit ribosomal RNA gene sequences from the hypotrichous ciliates Oxytricha nova and Stylonichia putalata. Mol Biol Evol 2:399410

Filatov DA (2002) ProSeq: a software for preparation and evolutionary analysis of DNA sequence data sets. Mol Ecol Notes 2:621-624

Fong CW, Lee SY, Wu RSS (2000) The effects of epiphytic algae and their grazers on the intertidal seagrass Zostera japonica. Aquat Bot 67:251-261

Glud RN, Kühl M, Wenzhöfer F, Rysgaard S (2002) Benthic diatoms of a high Arctic fjord (Young Sound, NE Greenland): importance for ecosystem primary production. Mar Ecol Prog Ser 238:15-29

Guillard RRL, Ryther JH (1962) Studies of marine planktonic diatoms. I. Cyclotella nana Hustedt and Detonula confervacea Cleve. Can J Microbiol 8:229-239

Hanelt D, Tüg H, Bischof K, Groß C, Lippert H, Sawall T, Wiencke C (2001) Light regime in an Arctic fjord: a study related to stratospheric ozone depletion as a basis for determination of UV effects on algal growth. Mar Biol 138:649-658

Hasle GR, Medlin LK, Syvertsen EE (1994) Synedropsis gen. nov., a sea ice associated araphid diatom genus. Phycologia 33:248270

Higgins D, Salemi M (2003). Multiple alignment-practice. In: Salemi M, Vandamme AM (eds) The phylogenetic handbook. Cambridge University Press, Cambridge, pp 61-71

Hop H, Pearson T, Hegseth EN, Kovacs KM, Wiencke C, Kwasniewski S, Eiane K, Mehlum F, Gulliksen B, WlodarskaKowalczuk M, Lydersen C, Weslawski JM, Cochrane S, Gabrielsen GW, Leakey RJG, Lønne JO, Zajaczkowski M, FalkPetersen S, Kendall M, Wängberg S, Bischof K, Voronkov AY, Kovaltchouk NA, Wiktor J, Poltermann M, di Prisco G, Papucci C, Gerland S (2002) The marine ecosystem of Kongsfjorden, Svalbard. Pol Res 21:167-208

Jerlov NG (1976) Marine optics. Elsevier, Amsterdam 
Karsten U, Klimant I, Holst G (1996) A new fluorimetric technique to measure growth of adhering phototrophic microorganisms. Appl Environ Microbiol 62:237-243

Longhi ML, Schloss IR, Wiencke C (2003) Effect of irradiance and temperature on photosynthesis and growth of two Antarctic benthic diatoms, Gyrosigma subsalinum and Odontella litigiosa. Bot Mar 46:276-284

Main SP, McIntire CD (1974) The distribution of epiphytic diatoms in Yaquina Estuary, Oregon (USA). Bot Mar 17:88-99

Medlin LK, Elwood HJ, Stickel S, Sogin ML (1988) The characterization of enzymatically amplified eukaryotic 16S-like rRNA-coding regions. Gene 71:491-499

Medlin LK, Kooistra WHC, Schmid AMM (2000) A review of the evolution of the diatoms - a total approach using molecules, morphology and geology. In: Witkowski A, Sieminska J (eds) The origin and early evolution of the diatoms: fossil, molecular and biogeographical approaches. W. Szafer Institute of Botany, Polish Academy of Sciences, Cracow, pp 13-35

Metzeltin D, Witkowski A (1996) Diatomeen der Bären-Insel. In: Lange-Bertalot H (ed) Iconographia diatomologica, vol 4. Koeltz Scientific Books, Königstein, 286 pp

Mock T, Gradinger R (1999) Determination of Arctic ice algae production with a new in situ incubation technique. Mar Ecol Prog Ser 177:15-26

Pillsbury RW, Lowe RL (1999) The response of benthic algae to manipulations of light in four acidic lakes in northern Michigan. Hydrobiologia 394:69-81

Pollard PC, Kogure K (1993) The role of epiphytic and epibenthic algae on the primary production of a tropical seagrass bed. Aust J Mar Fresh Res 44:141-154

Posada D, Crandall KA (1998) Modeltest: testing the model of DNA substitution. Bioinformatics 14:817-818

Poulin M (1990) Sea ice diatoms (Bacillariophyceae) of the Canadian Arctic. The genus Stenoneis. J Phycol 26:156-167

Poulin M (1993) Craspedopleura (Bacillariophyta), a new diatom genus of arctic sea ice assemblages. Phycologia 32:223-233

Poulin M, Berard-Therriault L, Cardinal A (1986) Fragilaria and Synedra (Bacillario-phyceae): a morphological and ultrastructural approach. Diatom Res 1:99-112

Ramm G (1977) Structure of epiphytic diatom populations of the phytal of the Kiel Bight (western Baltic). Nova Hed 54:379-387
Rivkin RB, Putt M (1987) Photosynthesis and cell division by Antarctic microalgae: comparison of benthic, planktonic and ice algae. J Phycol 23:223-229

Round FE (1971) Benthic marine diatoms. Oceanogr Mar Biol Annu Rev 9:83-139

Snoeijs P (1993) Intercalibration and distribution of diatom species in the Baltic Sea, vol 1. Opulus press, Uppsala, Sweden

Snoeijs P (1995) Effects of salinity on epiphytic diatom communities on Pilayella littoralis (Phaeophyceae) in the Baltic Sea. Ecoscience 2:382-394

Sokal PR, Rohlf FJ (1995) Biometry, 3rd edn. Freeman, New York

Svendsen H, Beszczynska-Møller A, Hagen JO, Lefauconnier B, Tverberg V, Gerland S, Ørbaek JB, Bischof K, Papucci C, Zajaczkowski M, Azzolini R, Bruland O, Wiencke C, Winther JG, Dallmann W (2002) The physical environment of Kongsfjorden-Krossfjorden, an Arctic fiord system in Svalbard. Pol Res 21:167-208

Swofford DL (2002) PAUP*, phylogenetic analysis using parsimony (*and other methods). Sinauer Associates, Sunderland

Thompson JD, Gibson TJ, Plewniak F, Jeanmougin F, Higgins DG (1997) The CLUSTAL_X windows interface: flexible strategies for multiple sequence alignment aided by quality analysis tools. Nucleic Acids Res 25:4876-4882

Underwood GJC, Kromkamp J (1999) Primary production by phytoplankton and microphytobenthos in estuaries. Adv Ecol Res 29:93-153

Wiencke C, Bartsch I, Bischoff B, Peters AF, Breemann AM (1994) Temperature requirements and biogeography of Antarctic, Arctic and amphiequatorial seaweeds. Bot Mar 37:247-259

Wiencke C, Vögele B, Kovaltchouk NA, Hop H (2004) Species composition and zonation of marine benthic macroalgae at Hansneset in Kongsfjorden, Svalbard. Rep Pol Mar Res 492:55-62

Witkowski A, Lange-Bertalot H, Metzeltin D (2000) Diatom flora of marine coasts. In: Lange-Bertalot $\mathrm{H}$ (ed) Iconographia diatomologica, vol 7. Koeltz Scientific Books, Königstein, 925 pp

Wlodarska-Kowalczuk M, Wesawski JM, Kotwicki L (1998) Spitzbergen glacial bays macrobenthos - a comparative study. Pol Biol 20:66-73 